\begin{tabular}{|c|c|c|}
\hline & JSM (10) (2) & \\
\hline & JURNAL SENI MUSIK & \\
\hline & https://journal.unnes.ac.id/sju/index.php/jsm/index & \\
\hline
\end{tabular}

\title{
Socio-Political Issues in the Songs of "Kapital" Group Band Released in 2014-2015
}

Moch. Dimas Galuh Mahardika

Master Program of History Education, Sebelas Maret University, 57125, Surakarta.

\begin{abstract}
Article Info
Submitted : July 2021

Revised : November 2021

Accepted : Novermber 2021

\section{Keywords:}

Extreme music; Socio-

Political Issues; Kapital

Band

Abstract

Music is an unlimited medium as a place to convey a message. Literally music is an arrangement of sounds that echo the rhythm and harmony produced from the instruments that can produce sounds. Literary art in this case also has an important position in the component of a musical work, considering the messages conveyed verbally by the composer are in this position. Lyrics/verses written in a musical work are often used as the main reference by listeners to understand and justify the idea of the composer. Not closing the possibility, the composer creates lyrics that are metaphorical to spark the imaginary power of the audience, so that in a musical composition there is a feeling embodied in a development. In this article we will see that literature in music embodied in song lyrics has a value, as well as being a medium that contains about a particular message. Kapital is a band from Tenggarong that performs metalcore music. The breadth of freedom expression in music, Kapital band used music as a place to make criticism of socio-political conditions. Kapital deliberately uses music as a medium of criticism because they realize that their audience will be able to maximum capture the message if the message contained in their songs is a relevant problem with social conditions. This article written using historical methods and the literature review approach, tried to briefly review socio-political issues in several songs released by Kapital band songs.
\end{abstract}




\section{INTRODUCTION}

Music as a form of extension of human instinct has a fairly deep aesthetic value, because music is formed on two things, the first is technical experience (talent), the second is the aesthetic experience (experimental psychology). The embodiment of the musical form, both in the original and in the reproductive sense, always depends on the influence of feelings. Perhaps this influence in certain things serves as a restraint (limitation) of feelings. In other respects, feelings also determine the color of the music created, so that if a composer creates a piece of music will be very personal to the listener's ears when the theme of the music they are stretching is based on personal experience (Dyndahl dkk., 2017).

Each composer has their own interests in making a musical work. The essence of their work is subjective based on something objective (real happening). It can be said that music is a representation of the composer's soul, this is similar to the theory of Experimental Psychology when their evidence was tested that a musical composition of high aesthetic value was created by technical experience and a qualified psychological experience. Music players need a certain emotional activity in order to achieve actual musical enjoyment by knowing the aesthetics of musical forms (Freeborn, 2002).

One type of music that concerns young people is rock music. The term rock means 'swing' or 'swing' which further develops into another meaning of the word rock itself which is 'coral' or 'rock' (Dahlan, 2009; Faulk, 2010). In its development, rock music has many new sub-genres featuring very high musical rhythms and tensions. One type of music that exists and develops in Indonesia is the flow of metalcore music. This genre is a term for the definition of the type of music combined from Hardcore music with Extreme Metal. This type of music appeared in the late 90's. When viewed from the historical line, it began in the early 80 's when hardcorepunk music was also influenced by heavy \& thrash metal music, and vice versa influenced each other. This type of music is thick with the characteristic of a high voltage guitar, distortion with a larger portion by using a low tone between the tones $\mathrm{D}$ to $\mathrm{A}$. Another characteristic of this type of music is the rhythm breakdown when all instruments play the rhythm together and massiv. Metalcore flourished in the '90s, initiated by Pantera who was considered the first band to introduce metalcore music (Kahn-Harris, 2006; Morris, 2015).

Discussing the early days of underground music in Indonesia, there are two important periods of the New Order period and the post-reform period. This is important because however the sociopolitical conditions in which a generation grows up are very influential in the formation of character, mentality, and attitude. The socio-political conditions during the New Order period were quite repressive in absolute affect the forms subcultures expression of young Indonesians at that time. At this time the world of music went straight and directed at the power of the government. Underground and indepent jargon becomes very "grand" and "sacred" as a form of opposition to everything that pops and majors (Hjelm dkk., 2012; Jube, 2008). The subculture of young people has a way of life, growth and development. They live in a country that is supposed to make room for such developments, but that is still not realized when the leader is still authoritarian and repressive. From the past even today subculture communities in Indonesia have tried to create alternative spaces that can accommodate their interests. In the 1990s, every time I heard the word "underground" and independent, what stuck to the minds of the lay people was metal, hardcore, punk, and the like (Daryana dkk., 2020).

The development of music in Indonesia cannot be separated from the role of the regime and political policy from time to time. In the Sukarno era, the influence of western music was severely limited because the ideology focused more on the formation of nationalist characters in accordance with the noble values of the nation. Sukarno was a very anti-western person, no exception in the field of music. He is quite getol in 
rejecting the influence of western music, because it is considered to be able to spread western thought through the medium of music. Western influence through music is considered a threat because it may open up the possibility for individualist cosmopolitanism to shift socialistnationalism values (Holt, 2007; Wallach, 2008). The restraint greatly impacted the existence of musicians who lived in that era, so in their work they had to move undercover to avoid repressive rulers.

As of 1966, when the regime changed, Sukarno was deposed after the G30S (Drakeley, 2005), and Suharto rose to the leadership as President, the situation changed very drastically. During Suharto's reign, various western influences in sharing aspects of life began to enter freely. That "well before New Order Indonesia was opened to economic activity, it was opened to American and British music" (Frederick, 1982). That before the domestic economy began to open cooperation with western countries, the influence of music from America and the British region had begun to enter and exerted a significant influence on the musical quality of musicians in Indonesia. Suharto's power on the one hand was a starting point for the stalemate of music development in Indonesia, especially the influence of rock n' roll music which gained serious repressiveity during Sukarno's time. New Order, is a term pinned to the political power of Suharto, as well as in the field of music New Order is also a "new era" in the development of western music influence, which in the future can give birth to musicians who have quality homeland. Concrete evidence of the various influences of western music that entered the New Order era gave birth to the first generation of rock bands in the ' 70 s that at the same time became the foundation of rock musicality in Indonesia. Of course these bands then made a huge impact on the development of the sub-genre of rock music they brought, which will provide a variety of colors in the country music industry in the future (Mahardika, 2021).

Kapital is one of the bands formed in Tenggarong. The band that performs the genre of metalcore music is one of the bands that are quite influential in the music scene in the region. Kapital is considered critical because of the song's sharp lyrics and nuanced criticism of the socio-political conditions in their surroundings. The author sees something interesting about the band's works and will present the substance of their song lyrics in this article.

\section{METHODS}

This article is the result of a study conducted by the author using historical methods with a library study approach. In its interpretation, historical methods are carried out in several stages (Gottschalk, 1969; Kuntowijoyo, 2005): (a) topic selection; (b) the collection of resources; (c) verification of sources; (d) interpretation; (e) historiography. Then the study of the library is one of the approaches that is considered appropriate and practical to tell the theme carried out by the author, because in the study of the author's library only study various studies from sources that are considered relevant to the theme to be discussed. Zed (2004) explains several characteristics of library research including: (a) the author comes face to face with the source. The author collects sources in the form of books, as well as scientific journals that are considered in accordance with the theme of the discussion; (b) the source is readymade. Ease of accessing resources is important because in research the text source library becomes the main material; (c) the source used is generally a source of skunder, the results of research in the form of books and scientific journals. This research is descriptive, because the results of the study and study of the author on the sources obtained in the form of narratives that tell about related themes. In practice, the author determines the theme of discussion related to socio-political issues in the song of the band Kapital. Then the author gathers various sources available on the internet in the form of scientific journals, as well as books relevant to the theme of the study. In addition, the author also utilizes the primary source of documentary videos available on the youtube platform. The video was 
produced by members of the band Kapital. Once the source is collected, the next stage is interpretation. The interpretation results are then written in narrative form according to the predetermined theme.

\section{RESULT AND DISCUSSION}

\section{The Asthetics of Music}

A work of music created will be subjective because it includes various internal components of the composer. In technical terms, music is instrumentally necessary to be given other components beyond the internal nature of the music itself. Such as the naming as the initial identity of a musical work, up to the biography of the composer. It is necessary because in understanding a musical work, an audience needs to recognize who and how the background of the composer so that the message that the composer wants to convey can be well received. This then makes the music aesthetically pleasing autonomously and heteronomously. Autonomous aesthetics are tasked with expressing specific and specific beauty, while heteronom aesthetics complement a work of music on beauty beyond music itself (Cope, 1989; Waesberghe, 2016).

The composition in a musical work has a fairly complex component. In terms of technical instrumentals, a composer will create notes that reflect the atmosphere of feeling in accordance with the theme carried, they can choose to play in the area of major-minor tones, of course also by adjusting to the basic tone they play. For example, such as the A major tone ladder is used for happy compositions, conversely the $\mathrm{B}$ minor tone ladder is used on compositions that reflect serious atmosphere, as well as the $\mathrm{F}$ minor tone ladder to impress the sad atmosphere. It can be said that that interpretation gives a special feature to the tone ladder that is maintained by most of the many composers (Toynbee, 2000).

Literary art in this case also has an important position in the component of a musical work, considering the messages conveyed verbally by the composer are in this position. Lyrics / verses written in a musical work are often used as the main reference by listeners to understand and justify the idea of the composer. Not closing the possibility, the composer creates lyrics that are metaphorical to spark the imaginary power of the audience, so that in a musical composition there is a feeling embodied in a development. In this article we will see that literature in music embodied in song lyrics has a value, as well as being a medium that contains about a particular message.

\section{A Short Biography of Kapital Band}

There is no special meaning of a name from "Kapital", just a word that is aesthetically visible and sounds easy to remember, and in the Indonesian dictionary that has a great meaning. The band was formed around 2004 under the name "The Pistol" with the personnel, Akbar Haka, Dhani arinda, David Haka, Beng, and Ivan Fahrani. By considering an identity to be more easily known in the future, they agreed to rename the band Kapital in 2007. Their career began when they released their first album titled "Metalmorhposis". In the process of making the first album, Dhani Arinda (Gitar) resigned, the guitar position held by Aji Hendra to help complete the first album that had been delayed. "Metalmorphosis" was released in 2009. After the release of their first album, Hendra (guitar) resigned, so Dhani Arinda (guitar) re-entered and continued to apply material for his next album. The second album titled "Reincarnation" was released in 2011. David Haka resigned in the middle of the promo process of this second album because he prefers to focus on working on the first album with his Stoner Rock band named "Biang Kerock". To fill the void, Gerhard joined Kapital and continued the process of applying material for his third album titled "Symphony kegelapan" released in 2012 (Iswari, 2015).

Kapital's journey starts with small gigs. It is from these gigs that they learn a lot and experience that the struggle in the process of a band's journey is very dynamic. There are times when their music is highly appreciated, but elsewhere their music is not necessarily accepted by connoisseurs. From that experience, they try to develop 
strategies to market and distribute their work whether it's cd recordings, merchandise, or other products they brand. Kapital tries to recall everything they've been through in their musical journey to come up with a strategy. The concept of "cause and effect" is the strategy they find for their marketing. In this concept they put together a thought that a well-established communication relationship would surely produce something much better. For example, when they are invited to perform in an event, they don't just play on stage and then finish. But one of the things they do is establish a lot of communication with fans, and the organizers. Because for them, by establishing communication with many parties, they will always be remembered. In essence, the responsibility between the band's players and the other parties is not only a technical responsibility, but a moral responsibility much more important (Maulyda dkk., 2019).

One of the important histories in the band's journey was when they released the album "Teror dari Belantara" in 2014, which at this event they invited one of the international bands, Municipal Waste from Virginia, USA. The album, released in 2014, contains 17 songs, some of which contain socio-political criticism that will be discussed in the next chapter. The band can be said to be very prolific considering that they have released more than three albums, and after the release of Teror dari Belantara album they also re-released the album "Anonymous EP" in 2015. In the lyrics of the song, they tell a realistic story. The lyrics they create are inseparable from their environment, in principle they write lyrics based on what they see, what they are with, what they feel, and what they are going through. They do so that the listener can more easily digest the meaning of the songs, and in all the lyrics they use Indonesian.

Kapital began to be much in demand and appreciated by their invitation in several major national music events such as Radio Show TV One, Bandung Berisik MMXII, Hammersonic, Kukar Rock In Fest (opening act Sepultura, Hellowen). Kapital felt what they achieved was just the early stages of the band's journey, and there were still a lot of big dreams out there that they hadn't achieved. But at least they have managed to show that, East Kalimantan can also speak a lot in the world of Indonesian underground music. Kapital's influenced musical characters from oldschool metal bands such as Judas Priest, Iron Maiden, Megadeth, Metallica to modern-day metals such as Lamb of God and Killswitch Engage. Kapital considers that the music they play remains at one root namely heavy metal, although in its development it is more touched by metalcore and hardcore. Lyrics that tell more about social and nature, made Kapital chosen to represent Kalimantan to play in the performance of Kutukan Kudungga directed by Butet Kertaradjasa and Djaduk Ferianto at TIM Jakarta September 2011 which tells about the damage of nature in The Earth Kalimantan / Indonesia.

\section{Socio-Political Issues Kapital Band Songs}

The focus of the discussion was on the content of socio-political issues contained in several songs from the band. After collecting several relevant sources for the writing of this article, the author created several lists of songs that are assumed to have the above-mentioned critical content. Some of these songs include (check out the following table):

Tabel 1. Kapital Band Song List

\begin{tabular}{|c|c|c|}
\hline $\begin{array}{l}\text { Song } \\
\text { Title }\end{array}$ & Album/Siingle & Year \\
\hline Gegap & Teror Dari & 2014 \\
\hline Gempita & $\begin{array}{l}\text { Belantara } \\
\text { Album }\end{array}$ & \\
\hline Gaza & $\begin{array}{l}\text { Teror Dari } \\
\text { Belantara } \\
\text { Album }\end{array}$ & 2014 \\
\hline $\begin{array}{l}\text { Teror } \\
\text { Dari }\end{array}$ & $\begin{array}{l}\text { Teror Dari } \\
\text { Belantara }\end{array}$ & 2014 \\
\hline Belantara & Album & \\
\hline $\begin{array}{l}\text { Mutu } \\
\text { Manikam }\end{array}$ & Single & 2014 \\
\hline $\begin{array}{l}\text { Klausa } \\
\text { Hipokrit }\end{array}$ & $\begin{array}{l}\text { Anonymous EP } \\
\text { (Mini Album) }\end{array}$ & 2015 \\
\hline
\end{tabular}

From some of the list of songs above, the author will try to interpret the messages contained in the songs by reading the lyrics, viewing video clips and interviews with band personnel in the primary source in the form of documentation vidio. Based on 
several sources relevant to the topic of discussion, this historiography has strong data in the sustainability of its writing (Distortion rockaholicompany. Teror Dari Belantara. Cd Recording. 2014). Here is an description of socio-political issues in some of the songs mentioned in the table above:

\section{Gegap Gempita}

This song was included on the album Teror Dari Belantara, as one of the songs that has an element of socio-political criticism. In this song, it is conveyed that today many people from certain groups are trying to expand the ideology / teachings that they bring in various ways. In these ways they unconsciously have an element of discrimination, other groups feel eliminated by the dominance of the early group. We know that in Indonesia has several groups of "religions", which in this song alluded to the phrase "cultural color of the religious chain". Currently religious life in Indonesia can be said to be still quite good, there is no conflict that is too serious for this religious matter. However, these vital things are used by some "people" who bring religion as a field for profit. Indirectly the mindset of today's youth is constrained by the primordilists of the group, assuming that their group is the most correct.

\section{Gaza}

The conflict on Palestinian soil to date has not found a meeting point for its resolution. Israeli territorial disputes on Palestinian lands make many people think that this conflict is a religious conflict, but it is actually a matter of political interest. The length of this conflict inspired Kapital to package it in a song. The point of view in this song is not focused on religion, nor politics, but Kapital considers this to be a humanitarian tragedy. This prolonged conflict has resulted in many fatalities ranging from toddlers to the elderly as well as victims. We don't know what exactly happened, but it's clear that violence and human rights abuses are happening there. The song was also included on the album Terror of the Wilderness and was deliberately created to make listeners more sensitive to such controversial situations. In this song more about the human side in the middle of the conflict (Distortion Rockaholicompany. Gaza. video. 2014).

\section{Teror dari Belantara}

Kapital lives in East Kalimantan, where it is known for its dense forests and is often said to be the lungs of the world. Natural wealth in Kalimantan's forests is often misused by certain parties to dredge up resources and be overused. Seeing this reality, Kapital tried to tell his grievances about the exploitation of natural resources through a song titled "Teror Dari Belantara" which also became the name of their fourth album. The Song of Teror Dari Belantara is one of the representations of the exasperation of the Kalimantan People towards the exploitation of natural resources, and Kapital is able to represent the voices and aspirations of the people of East Kalimantan. In the lyrics it is very clear that satire about natural conditions is beginning to decline as a result of exploitation. These musicians, they can voice anything they want to say, including those who are sensitive to the surrounding environment who can't bear to see the land they live in is controlled by irresponsible parties.

\section{Mutu Manikam}

Mutu Manikam is an allusion in Kalimantan language, which means "various gems". Lagu Mutu Manikam is a single released in 2016. Indonesia is not only rich in natural resources, but Indonesia is also rich in culture in each region. In the midst of the rise of industrialization and globalization, Kalimantan cultures began to sink slightly. People are more aussical with their modernity in everyday life. In this song still talks about exploitation, when the forests are depleted for industrial purposes, and also not a few forests are burned. One of the interesting things in this song is the composition of music that combines modern music with ethnic music. In one part of the song, there are chromatic tones with the passage "Sampeq", a typical Dayak musical instrument filled to collaborate with Kapital music. By combining elements of modern music with ethnic music can 
indirectly prove that the universal nature of music is very absolute, that any kind of music can be collaborated with other types of music. At the same time Kapital wants to keep their native culture, in addition to the modern music they bring (Distortion Rockaholicompany. Mutu Manikam. Video clip. 2016).

\section{Klausa Hipokrit}

After releasing the album Terror Dari Belantara in 2014, Kapital re-released the EP mini album "Anonymous" in 2015. On the album there are six songs, two of which contain socio-political criticism, Klausa Hipokrit (hypocritical clauses) one of them. When referring to the Great Dictionary of The Indonesian Language, the clause has the meaning of a grammatical unit in the form of a group of words consisting of subjects, objects and predicates that have the potential to become sentences. While hypocritical has the meaning of people who like to pretend. In general, the author assumes that the Hypocritical Clause is a criticism and satire to politicians who like to rhetoric for personal or group interests only. Dirty political games have an impact on divisions in society, especially to people who do not fully understand politics but they have gained doctrine from certain political groups. So it is the interests of each group that ultimately make various confusions to the way people view that is not directly involved in politics. The rapid development of technology has an impact on the rapid dissemination of information. Not infrequently also a lot of news dramatized from real facts in the field, or more often known as hoaxes. Social media has a considerable role in the formation of the way people view things, especially in the lay community. If social media presents objective news, of course the public will receive factual truth from the information. But the problem today is that social media/electronic media sometimes leans towards a party, they provide information that is full of subjectivity and still far from objective words. This is the main discussion in the song Hypocritical Clause, because of the chaotic political conditions, society will be affected. As well as social media that is sometimes unable to guarantee the truth of an information, so that the lay people also have an "instant" view of the information they get (Distortion Rockaholicompany. Behind The Scene EP Album Anonymous. video. 2015).

\section{CONCLUSION}

Music is one of the mediums to represent one's soul, of many things they have experienced in their daily life, as a place to express what they are feeling. Many types of music exist in this era, and everyone has the right to choose what kind of music they feel suits themselves. When talking about music, at the same time we talk about tastes. Everyone has their own tastes that are certainly different from each other and tastes are something that cannot be forced. Not only for entertainment media, music can also be a place to express criticism of everything that is not fit in context. This is much better than writing or criticizing through social media, which then only leads to misunderstandings and leads to fake news. In fact music is universal, anyone can play music, anywhere and anytime.

Music is not only intended for people in certain groups/classes, music can be enjoyed by anyone regardless of status or position. Of the many types of music, collaborations between types of music are also often done by musicians in this era. They are no longer fixated by one type of music alone, but they are more daring to explore in each of his works. The submission contained in the lyrics of the song also determines whether the work is accepted by music lovers. If we talk about the condition of Indonesian society, it is not possible if music lovers in Indonesia are always treated to lyrics that smell satanic, violent or "extreme" themes such as those by international musicians. Musicians should know the situation and conditions in which they work and present their work, so that their work can be accepted and enjoyed by the people around them. 


\section{REFERENCES}

Cope, D. (1989). New Directions in Music (5th ed). W.C. Brown.

Dahlan, T. (2009). Sejarah Musik 2.

Fakultas Bahasa dan Seni UNY.Daryana, H. A., Priyatna, A., \& Mulyadi, R. M. (2020). The New Metal Men: Exploring Model of Flexible Masculinity in the Bandung Metal Scene. Masculinities \& Social Change, 9(2), 148. https://doi.org/10.17583/mcs.2020. 5020

Drakeley, S. (2005). The History of Indonesia. Greenwood Press.

Dyndahl, P., Karlsen, S., Nielsen, S. G., \& Skårberg, O. (2017). The Academisation of Popular Music in Higher Music Education: The Case of Norway. Music Education Research, 19(4), 438-454. https://doi.org/10.1080/14613808.2 016.1204280

Faulk, B. J. (2010). British Rock Modernism, 1967-1977: The Story of Music Hall in Rock. Ashgate.

Frederick, W. H. (1982). Rhoma Irama and the Dangdut Style: Aspects of Contemporary Indonesian Popular Culture. Indonesia, 34, 103-130.

Freeborn, R. (2002). Confronting the Dark Side of the Beat: A Guide to Creating a Heavy Metal Music Collection. Music Reference Services Quarterly, 8(2), 25-37.

https://doi.org/10.1300/J116v08n0 2_03

Gottschalk, L. (1969). Understanding History: A Primer of Historical Method. Knopf.

Hjelm, T., Kahn-Harris, K., \& Levine, M. (2012). Heavy Metal as Controversy and Counterculture. Popular Music History, 6(1), 5-18.

Holt, C. (Ed.). (2007). Culture and Politics in Indonesia (1st Equinox ed). Equinox Pub.

Iswari, F. M. (2015). Representasi Pesan Lingkungan Dalam Lirik Lagu Surat Untuk Tuhan Karya Group Musik "Kapital" (Analisis Semeotika). eJournal Ilmu Komunikasi, 3(1), 254268.
Jube. (2008). Musik Underground Indonesia: Revolusi Indie Label. Harmoni.

Kahn-Harris，K. (2006). Extreme Metal: Music and Culture on the Edge. Berg.

Kuntowijoyo. (2005). Pengantar llmu Sejarah. Bentang Pustaka.

Mahardika, M. D. G. (2021). Empat Pilar Thrash Metal: The Big Four dan Pengaruhnya Terhadap Skena Musik Ekstrim Indonesia Era 90' An. Historia Vitae, 1(1), 14-26.

Maulyda, M., Erawan, E., \& Dwivayani, K. D. (2019). Makna Lirik Lagi "Teror dari Belantara" oleh Band Kapital. eJournal Ilmu Komunikasi, 7(3), 1-14.

Morris, M. (2015). Extreme Heavy Metal Music and Critical Theory. The Germanic Review: Literature, Culture, Theory, 90(4), 285-303. https://doi.org/10.1080/00168890.2 015.1096167

Toynbee, J. (2000). Making Popular Music: Musicians, Creativity and Institutions. Arnold; Co-published in the U.S.A. by Oxford University Press.

Waesberghe, F. H. S. (2016). Estetika Musik. Thafa Media.

Wallach, J. (2008). Modern Noise, Fluid Genres: Popular Music in Indonesia, 1997-2001. University of Wisconsin Press.

\section{Documentary Video \& CD Album's}

Kapital. 2014. Terror Dari Belantara (CD Album), Borneo: Distorsi Rockaholicompany.

Kapital. 2014. Gaza (Video), Borneo: Distorsi Rockaholicompany.

Kapital. 2015. Behind The Scene EP Album Anonymous (Part 2), Borneo: Distorsi Rockaholicompany.

Kapital. 2014. Gaza (Video), Borneo: Distorsi Rockaholicompany.

Kapital. 2016. Mutu Manikam (Video), Borneo: Distorsi Rockaholicompany. 